\title{
Peran PTUN dan AUPB Menuju Tata Kelola Pemerintahan yang Baik (Good Governance) ${ }^{*}$
}

\author{
Aju Putrijanti**, Lapon T. Leonard ${ }^{* * *}$, dan Kartika Widya Utama ${ }^{* * * *}$ \\ Hukum Acara Peradilan Tata Usaha Negara, Fakultas Hukum, Universitas Diponegoro \\ Jl. Prof Soedarto. Tembalang, Semarang. 50272
}

\begin{abstract}
The Administrative Court has an important role to supervise the government's duty, based on principle of good governance and regulations. Principles of good governance have been developed for some reasons. The aim of this research are to know the role of judge's verdict and the development of principle of good governance. This research is use normative juridis method. The novelty is to strengthened the role of the judge's verdict to build a good governance and to improve the knowledge of the importance of principles of good governance to build good governance.
\end{abstract}

Keywords: Administrative Court, Principle of Good Governance, Good governance.

\section{Intisari}

Pengadilan Tata Usaha Negara memiliki peran penting dalam melakukan pengawasan terhadap penyelenggaraan pemerintahan yang didasarkan pada pengujian terhadap Asas-asas Umum Pemerintahan yang Baik dan perundang-undangan. Asas-asas Umum Pemerintahan yang Baik telah mengalami perkembangan yang penting. Tujuan yang akan dicapai adalah untuk mengetahui peran putusan Hakim dan perkembangan Asas-asas Umum Pemerintahan yang Baik.Penelitian menggunakan metode yuridis normatif. Keterbaruan yaitu meningkatkan peran Pengadilan Tata Usaha Negara dan kemampuan untuk lebih memahami arti penting Asas-asas Umum Pemerintahan yang Baik menuju tata kelola yang lebih baik.

Kata Kunci: Pengadilan Tata Usaha Negara, Asas-asas Umum Pemerintahan yang Baik, tata kelola pemerintahan.

\section{Pokok Muatan}

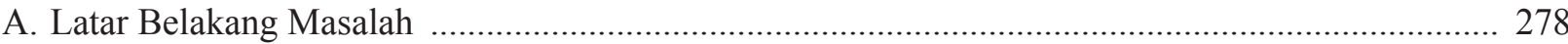

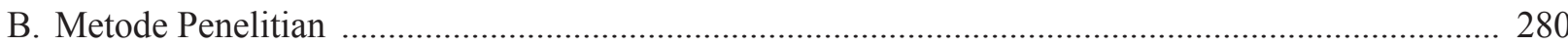

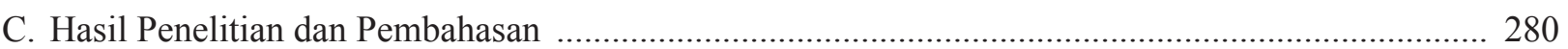

1. Perkembangan Asas Umum Pemerintahan yang Baik (AUPB) dikaitkan dengan Undang-Undang Nomor 30 Tahun 2014 tentang Administrasi Pemerintahan ........................... 280

2. Peran Pengadilan Tata Usaha Negara untuk Membangun Tata Kelola Pemerintahan

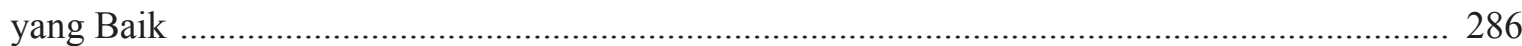

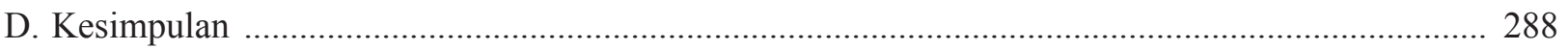

Penelitian Riset Pengembangan dan Penerapan (RPP). Dibiayai dengan Sumber Dana Selain APBN Dipa Sukpa LPPM Universitas Diponegoro Tahun Anggaran 2017.

** Alamat korespondensi : aputriyanti@yahoo.com.

*** Alamat korespondensi : leo_tukan@yahoo.com.au.

***** Alamat korespondensi : kartikawidyautama.undip@gmail.com. 


\section{A. Latar Belakang Masalah}

Undang-Undang Nomor 30 Tahun 2014 tentang Administrasi Pemerintahan (selanjutnya disebut UU AP) bertujuan agar penyelenggaraan pemerintahan lebih sesuai dengan harapan dan kebutuhan masyarakat (citizen friendly) dan sebagai landasan dan pedoman bagi Badan dan / atau Pejabat Pemerintahan dalam melaksanakan tugas pemerintahan. Selain untuk menjamin hakhak dasar warga negara, UU AP juga merupakan transformasi Asas- asas Umum Pemerintahan yang Baik (selanjutnya disebut AUPB) yang selama ini telah dipraktikkan serta dikonkretkan dalam bentuk norma hukum yang mengikat.

AUPB sangat diperlukan untuk membangun tata kelola pemerintahan yang baik dan pengawasan penerapannya dilakukan oleh Pengadilan Tata Usaha Negara (PTUN) yang sekaligus melakukan fungsi peradilan untuk memberi akses keadilan bagi masyarakat. Pengawasan yang dilakukan oleh PTUN adalah pengawasan represif dan hanya menilai segi legalitas dari tindakan hukum pemerintah terutama surat keputusan tata usaha negara. ${ }^{1}$ PTUN memeriksa terkait dengan terbitnya surat keputusan tata usaha negara, mengenai kewenangan, prosedur serta substansi dalam surat keputusan

Sesuai Pasal 10 ayat (1) UU AP dicantumkan 8 AUPB, dan dalam Pasal 10 ayat (2) menyebutkan asas-asas umum lainnya selain yang disebutkan diatas, dapat diterapkan sepanjang dijadikan dasar penilaian hakim yang dituangkan dalam putusan pengadilan. Bertitik tolak dari hal tersebut, PTUN memiliki peran penting untuk mengawasi pemerintahan agar sesuai dengan AUPB dan membangun tata kelola pemerintahan yang baik.

Hasil penelitian sosio-legal mengenai Asas-asas Umum Pemerintahan yang Baik dalam Perkara Tata Usaha Negara yang diselenggarakan oleh Judicial Sector Support Programme (sesuai permintaan dari MARI, KY dan Kejaksaan Agung melalui Judicial Reform Team Office and The Prosecutor Reform Project Office), perlu diperhatikan mengenai keberadaan AUPB sebagai norma penguji tersendiri, kewenangan Hakim dalam menguji norma AUPB, faktor-faktor eksternal dalam penerapan AUPB, yang kesemuanya saling berhubungan dan penting dalam penyelenggaraan pemerintahan. $^{2}$

Penyelenggaraan pemerintah dalam pelayanan publik seringkali menimbulkan ketidakpuasaan masyarakat, hal ini menunjukkan masih kurangnya penerapan tata kelola pemerintahan yang baik, yang dapat menimbulkan maladministrasi dan merugikan masyarakat. Upaya pemerintah secara normatif untuk memperbaiki dan meningkatkan penyelenggaraan pemerintah sudah dilakukan, namun demikian, hal tersebut belum banyak berpengaruh terhadap perilaku pelayanan publik yang masih cenderung lama, tidak efektif dan tertutup, dan juga disebabkan oleh penegakan hukum dan kepastian hukum terhadap tatanan perubahan perilaku pelayanan publik yang belum diatur secara baik. ${ }^{3}$

Dikutip dari B. Arief Sidharta, pandangan Scheltema yang merumuskan tentang unsurunsur dan asas-asas negara hukum secara baru, yang antara lain menyebutkan asas-asas umum pemerintahan yang layak sebagai salah satu asas penting dalam penyelenggaraan pemerintahan bahwa pemerintah dan pejabat pemerintah sebagai pelayan masyarakat serta mewujudkan tujuan negara. ${ }^{4}$

PTUN memiliki tugas untuk memeriksa, memutus dan menyelesaikan sengketa tata usaha negara, hal ini tercantum dalam Pasal 47 UndangUndang Nomor 5 Tahun 1986 tentang Peradilan Tata Usaha Negara. Adapun fungsi pengawasan di PTUN

Irfan Fachruddin, 2004, Pengawasan Peradilan Administrasi Terhadap Tindakan Pemerintah, Alumni, Bandung, hlm. 255.

Supandi, 2016, Hukum Peradilan Tata Usaha Negara, Alumni, Bandung.

Cekli Setya, et al., 2017, Asas-Asas Umum Pemerintahan Yang Baik Dalam Perkara Tata Usaha Negara, Lembaga Kajian dan Advokasi Independensi Peradilan Judicial Sector Support Program, Jakarta, hlm. 19-22.

B. Arief Sidharta. "Kajian Kefilsafatan tentang Negara Hukum “, Jentera Jurnal Hukum, Pusat Studi Hukum dan Kebijakan, Jakarta, Edisi 3 Tahun II November 2004, hlm. 124 - 125. 
sejalan dengan fungsi peradilan sebagai pelaksanaan tugas dan fungsi badan peradilan tersebut. Antara fungsi pengawasan dan fungsi peradilan tidak dapat dipisahkan terkait dengan penyelenggaraan pemerintahan yang harus memperoleh pengawasan eksternal maupun internal. PTUN melakukan pengujian terhadap Keputusan Tata Usaha Negara berdasarkan peraturan perundangan yang berlaku serta asas-asas umum pemerintahan yang baik.

Menurut Irfan Fachruddin pengawasan oleh peradilan administrasi termasuk pengawasan yang "independen" yaitu pengawasan yang dilakukan oleh badan yang secara organisatoris berada di luar pengaruh dan lingkungan administrasi negara. ${ }^{5} \mathrm{Ada}$ beberapa macam jenis pengawasan, yang dapat dibedakan dari sifat, jenis, pengawasan segi hukum dan segi kemanfaatan, dan pengawasan yang dilakukan oleh badan peradilan mempunyai ciri-ciri, pertama ekstern, karena dilakukan oleh suatu badan di luar pemerintahan, kedua, a-posteriori karena selalu dilakukan sesudah terjadinya perbuatan yang dikontrol, ketiga, kontrol segi hukum karena hanya menilai dari segi hukum saja.

Menurut Paulus Effendi Lotulung dari sisi pengawasan, asas legalitas sangat diperhatikan di samping asas efisiensi dan efektivitas sebagai perwujudan dari prinsip negara hukum, yang oleh Julius Stahl dikatakan bahwa salah satu sendi atau pilar negara hukum adalah keabsahan hukum dari tindakan pemerintahnya. Pengawasan oleh badan peradilan diperlukan demi tegaknya negara hukum dan perlindungan hak asasi manusia.

Pengawasan melalui peradilan dapat dilihat dalam putusan Hakim, yaitu pengujian terhadap AUPB dan asas hukum administrasi terkait dilakukan sesuai dengan obyek sengketa. Menurut Soedikno Mertokusumo, putusan Hakim tidak berdiri sendiri, tetapi mempunyai kekuatan berlaku untuk peristiwa serupa yang terjadi kemudian, hal ini untuk kepastian dan kesatuan hukum. Dalam sistem hukum Civil Law, putusan hakim atau yurisprudensi tidak bersifat mengikat hakim (not legally binding - the persuasive precedent) selanjutnya, dan jelas berbeda dengan sistem hukum Common Law yang mengutamakan putusan hakim bersifat mengikat selain perundang-undangan yang ada (the binding precedent).

Putusan Hakim PTUN memiliki peran penting dalam menegakkan hukum administrasi negara terkait dengan tata kelola pemerintahan yang baik, karena dapat melakukan penemuan hukum tentang asas-asas hukum terutama terkait dengan AUPB. Pengaturan oleh Pemerintah mengenai tata kelola pemerintahan yang baik sudah diupayakan dengan mencantumkan AUPB di beberapa perundangan.

Yulius Rivai menjelaskan bahwa putusan Hakim dapat dilihat dari segi ontologi, epistemologi dan aksiologi. Artinya bahwa putusan Hakim memiliki obyek tersendiri, agar dapat memberikan putusan, Hakim harus memiliki suatu penalaran maupun argumentasi, sehingga putusan yang dihasilkan memiliki kegunaan secara teori dan praktek. ${ }^{6}$ Mengenai kegunaan putusan Hakim, Purwoto S.Gandakusuma menyebutkan bahwa putusan Hakim yang baik harus memenuhi 2 (dua) syarat utama, pertama, memenuhi kebutuhan teoritis yaitu putusan harus dapat dipertanggungjawabkan dari segi ilmu hukum yang dengan putusannya dapat membentuk yurisprudensi, kedua, memenuhi kebutuhan praktis yaitu dengan diharapkan Hakim dapat menyelesaikan sengketa hukum dan sejauh mungkin dapat diterima oleh pihak yang bersengketa dan masyarakat. ${ }^{7}$

Penyelenggaraan pemerintah harus berorientasi memberi pelayanan publik yang baik, transparan, memberi hak dan kewajiban kepada warga masyarakat, memberi perlindungan hukum dari tindakan pemerintah. Sehubungan dengan

\footnotetext{
Irfan Fachruddin, Op.cit., hlm. 258.

Yulius Rivai, "Putusan Hakim Sebagai Suatu Ilmu", dalam Subur, et al., 2014, Bunga Rampai Peradilan Administrasi Kontemporer, Genta Publishing, Yogyakarta, hlm. 89-100.

Asmuni, 2017, Konsep Pelaksanaan Keputusan Tata Usaha Negara Penundaan Pelaksanaan Keputusan Tata Usaha Negara Oleh Pengadilan Tata Usaha Negara, Setara Press, Malang, hlm. 90.
} 
tata kelola pemerintahan yang baik, tujuan yang akan dicapai yaitu pertama, untuk mewujudkan berbagai kepastian, kemudahan dan keberhasilan dalam pelayanan publik, kedua untuk memberi perlindungan kepada rakyat dari tindakan sewenangwenang pemerintah. ${ }^{8}$

Berdasarkan atas uraian di atas, terdapat 2 (dua) permasalahan yang dibahas adalah pertama, bagaimana perkembangan AUPB dikaitkan dengan Undang-Undang Nomor 30 Tahun 2014 tentang Administrasi Pemerintahan?; kedua, bagaimana peran PTUN untuk membangun tata kelola pemerntahan ntahan yang baik?

\section{B. Metode Penelitian}

Penelitian ini menggunakan metode normatif dan menggunakan bahan hukum primer dan bahan hukum sekunder. Bahan hukum primer mempunyai sifat autoritatif artinya mempunyai otoritas. Bahan hukum primer terdiri dari peraturan perundang-undangan dan putusan Hakim yang telah memperoleh kekuatan hukum tetap. Putusan Pengadilan adalah bahan hukum primer yang memiliki otoritas, karena merupakan konkretisasi dari perundang-undangan. Putusan Pengadilan inilah sebenarnya yang merupakan law in action.

Analisa data dimulai dengan melakukan inventarisasi seluruh peraturan perundangan yang merupakan bahan hukum primer, untuk selanjutnya dikelompokkan sesuai dengan jenis yang diperlukan. Pengelompokkan data yang berupa putusan pengadilan untuk lebih memudahkan proses analisa data.

Kegiatan analisa data dilakukan secara sistematis sesuai dengan teori yang digunakan untuk disusun sebagai kesimpulan yang menjawab permasalahan.

\section{Hasil Penelitian dan Pembahasan \\ 1. Perkembangan Asas Umum Pemerintahan yang Baik (AUPB) dikaitkan dengan Undang-Undang Nomor 30 Tahun 2014 tentang Administrasi Pemerintahan.}

Tata kelola pemerintahan yang baik selalu berkembang serta mengikuti perkembangan global, tidak mungkin hanya bersifat nasional saja. Penyelenggaraan pemerintahan adalah untuk memberi pelayanan publik kepada masyarakat, yang dipengaruhi oleh dinamika politik, ekonomi, perkembangan teknologi informasi, sosial budaya yang kesemuanya bercampur dan memberi pengaruh penyelenggaraan pemerintahan.

Penyelenggaraan pemerintahan di negara maju tentu berbeda dengan negara berkembang, beberapa faktor penting memberi pengaruh, yaitu cara berpikir yang mengutamakan kualitas pelayanan, transparansi, integritas, kapasitas pengembangan kemampuan dan didukung oleh hal lain bersifat non-teknis tetapi sangat menunjang terwujudnya tata kelola pemerintahan yang baik. Penyelenggaraan pemerintahan tidak hanya ditentukan oleh bagaimana pemerintah bekerja tetapi juga ditentukan oleh kebijakan yang diambil untuk kesejahteraan warga. ${ }^{9} \quad$ Kebijakan yang dilaksanakan pun tetap harus berdasarkan AUPB dan peraturan perundangan yang berlaku.

Perkembangan AUPB dapat dibagi dalam 3 fase. Fase pertama adalah bahwa secara historis penggunaan AUPB sudah berlangsung sejak lama. Penggunaan AUPB tidak didasarkan pada landasan hukum dalam bentuk normatif yaitu undang-undang atau peraturan perundangan lainnya, namun lebih diutamakan berdasarkan konsep, doktrin, kebiasaan yang timbul dalam praktek penyelenggaraan negara.

Pada fase kedua, normativasi AUPB pertama kali dilakukan dalam Undang-Undang Nomor 28 Tahun 1999 tentang Penyelenggara Negara yang Bersih dan Bebas dari Korupsi, Kolusi dan 
Nepotisme. Ditegaskan bahwa pembentukkan Undang-Undang Nomor 28 Tahun 1999 tentang Penyelenggara Negara yang Bersih dan Bebas dari Korupsi, Kolusi dan Nepotisme merupakan bagian atau subsistem dari peraturan perundang-undangan berkaitan dengan penegakan hukum di bidang korupsi, kolusi dan nepotisme. Fungsi AUPB adalah untuk mewujudkan penyelenggaraan negara yang bersih dan bebas dari korupsi, kolusi dan nepotisme. Jadi, sebenarnya tidak mengatur sama sekali mengenai penyelenggaraan administrasi pemerintahan, yang menjadi urat nadi pelaksanaan pelbagai fungsi dan tugas pemerintah.

Fase ketiga adalah setelah Undang-Undang Nomor 30 Tahun 2014 tentang Administrasi Pemerintahan disahkan sebagai perundangan yang pertama kali mengatur mengenai tata laksana pemerintahan yang sesuai dengan UUD NRI 1945 dan Pancasila. Hal-hal penting terkait penyelenggaraan pemerintahan mulai dari kewenangan, wewenang, AUPB, atribusi, delegasi, mandat, larangan penyalahgunaan wewenang, diskresi, keputusan berbentuk elektronis, izin, dispensasi, konsesi, konflik kepentingan, sosialisasi yang harus dilakukan oleh Pemerintah, standar operasional prosedur, syarat sahnya keputusan, legalisasi dokumen, sanksi administratif diatur secara jelas.

Peraturan perundangan yang mencantumkan AUPB selain Undang-Undang Nomor 30 Tahun 2014 tentang Administrasi Pemerintahan, UndanUndang Nomor 9 Tahun 2004 tentang Perubahan Atas Undan-Undang Nomor 5 Tahun 1986 tentang PTUN, Undan-Undang Nomor 28 Tahun 1999 tentang Penyelenggaraan Negara yang bersih dan bebas dari Korupsi, Kolusi dan Nepotisme karena sebagai syarat materiil pengajuan gugatan ke PTUN, adalah Undan-Undang Nomor 37 Tahun 2008 tentang Ombudsman, Undan-Undang Nomor 5 Tahun 2014 tentang Aparatur Sipil Negara, Undan-Undang Nomor 25 Tahun 2009 tentang Pelayanan Publik, Undan-Undang Nomor 23 Tahun 2014 tentang Pemerintahan Daerah, meskipun ada perbedaan istilah, definisi namun tetap menunjukkan sebagai AUPB. ${ }^{10}$

Undang-Undang Nomor 30 Tahun 2014 tentang Administrasi Pemerintahan sangat diperlukan bagi semua pihak, baik pemerintah, masyarakat serta PTUN dengan faktor kepentingan yang berbeda tetapi secara keseluruhan memiliki persamaan yaitu untuk meningkatkan tata kelola pemerintahan yang baik. Selain berdasarkan peraturan perundang-undangan, penyelengaraan pemerintahan juga berdasarkan AUPB baik yang telah dicantumkan dalam perundang-undangan, maupun putusan hakim yang telah berkekuatan hukum tetap serta praktek pemerintahan.

Sebagai upaya mewujudkan tata kelola pemerintahan yang baik, AUPB harus di gunakan sebagai dasar penyelenggaraan pemerintahan Hubungan antara PTUN, Pemerintahan dan Masyarakat serta kedudukan AUPB adalah penting. PTUN melaksanakan fungsi pengawasan dan fungsi peradilan, Pemerintah menyelenggarakan pemerintahan, serta masyarakat sebagai warga negara yang berhak memperoleh pelayanan dari Pemerintah serta mengajukan gugatan ke PTUN dan AUPB yang menjadi dasar bagi pemerintah dalam penyelenggaraan tugas dan fungsi serta sebagai batu uji terhadap keputusan tata usaha negara yang digugat.

\section{Bagan 1.}

\section{Kedudukan AUPB dalam hubungan Pemerintah, masyarakat, PTUN}

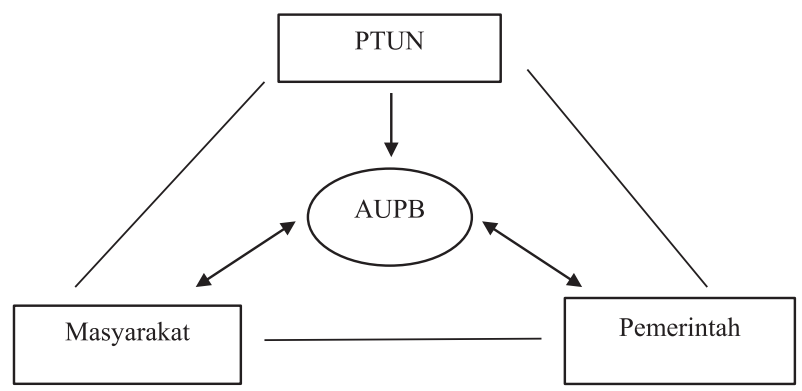

AUPB mulai dibentuk oleh Pejabat dan/atau Badan Tata Usaha Negara sejak saat dituangkannya

10 Cekli Setya, et.al, Op.cit., hlm. 23. 
atau dimasukkannya dalam suatu keputusan dan atau peraturan kebijaksanaan yang dikeluarkannya. ${ }^{11}$ Sehingga pembentukan AUPB tergantung pada tingkat kedudukan Pejabat dan/atau Badan Tata Usaha Negara, artinya dapat dibentuk oleh Presiden atau siapapun yang berdasarkan peraturan perundangan yang berlaku memiliki kewenangan sesuai perundang-undangan.

Pencantuman AUPB dalam Pasal 10 UndangUndang Nomor 30 Tahun 2014 tentang Administrasi Pemerintahan lebih lengkap dan menguntungkan bagi semua pihak. Mengingat pentingnya AUPB, pencantuman secara normatif seharusnya menjadi dasar hukum dan pertimbangan bagi Pejabat atau Badan Tata Usaha Negara dalam membuat keputusan agar lebih teliti dengan memperhatikan secara cermat dan menempatkan AUPB sebagai dasar utama penyusunan keputusan dan/atau tindakan secara tepat dan benar.

Menurut hasil penelitian dapat diketahui bahwa kekurangpahaman maupun kekurangtelitian dalam menempatkan AUPB sebagai dasar penyusunan keputusan, menjadi penyebab gugatan di PTUN, hal ini dapat dilihat pada syarat materiil pengajuan gugatan. AUPB sebagai suatu asas yang ada namun untuk penerapannya dalam penyusunan keputusan dan/atau tindakan belum sepenuhnya diterapkan.

Undang-Undang Nomor 9 Tahun 2004 tentang Perubahan Atas Undang-Undang Nomor 5 Tahun 1986 tentang Peradilan Tata Usaha Negara dalam Pasal 53 ayat (2) diubah yang terkait dengan alasan-alasan yang dapat digunakan sebagai dasar gugatan yaitu keputusan tata usaha negara yang digugat bertentangan dengan peraturan perundangundangan yang berlaku dan bertentangan dengan AUPB. Adapun sesuai dengan penjelasan, AUPB yang dimaksud yaitu AUPB sebagaimana tercantum dalam Undang-Undang Nomor 28 Tahun 1999 tentang Penyelenggaraan Negara yang Bersih dan Bebas dari Korupsi, Kolusi dan Nepotisme.
AUPB dalam Sistem Peradilan Tata Usaha Negara memiliki 2 fungsi, yaitu sebagai syarat mengajukan gugatan dan sebagai batu uji terhadap keputusan tata usaha negara. Sebelum Undang-Undang Nomor 9 Tahun 2004 tentang tentang Perubahan Atas Undang-Undang Nomor 5 Tahun 1986 tentang Peradilan Tata Usaha Negara berlaku, belum ada penggunaan AUPB sebagai salah satu dasar untuk mengajukan gugatan. Hal ini karena alasan untuk mengajukan gugatan masih berdasarkan ketentuan Pasal 53 ayat (2) Undang-Undang Nomor 5 Tahun 1986 tentang Peradilan Tata Usaha Negara. Setelah UndangUndang Nomor 9 Tahun 2004 tentang tentang Perubahan Atas Undang-Undang Nomor 5 Tahun 1986 tentang Peradilan Tata Usaha Negara berlaku, AUPB banyak diajukan sebagai salah satu dasar mengajukan gugatan. Pengajuan ini selaras dengan obyek sengketa yang dalam penerbitannya kurang memperhatikan asas kecermatan, asas kepastian hukum, keterbukaan, tidak menyalahgunakan wewenang, ketidak berpihakan dan AUPB terkait.

Penggunaan AUPB sebagai dasar pengajuan gugatan sesuai dengan Pasal 53 ayat (2) UndangUndang Nomor 9 Tahun 2004 , dan berhubungan dengan kekurangpahaman serta kekurangtelitian dalam menerapkan AUPB secara benar. Hal ini dapat dikatakan sebagai salahsatu indikator penting untuk meningkatkan kemampuan yang dimiliki dalam kapasitas sebagai penyelenggara pemerintahan, baik pejabat atau badan tata usaha negara. Kapasitas sebagai penyelenggara negara ini yang perlu untuk dipahami secara benar, karena dengan kapasitas tersebut kewenangan yang ada dapat dilaksanakan dengan benar.

Kewajiban bagi setiap pihak yang berkepentingan terhadap pemerintahan untuk menempatkan AUPB sebagai hal utama. Pemerintah sebagai penyelenggara pemerintahan harus berhati-hati, cermat dan teliti dalam setiap penyusunan keputusan dan/atau tindakan yang dibuat dan/atau dilakukan. 
Secara normatif sudah ada pengaturan yang jelas mengenai hal tersebut, selain itu penyelenggaraan pemerintahan tetap harus memperhatikan norma, prinsip dan asas pemerintahan yang bersifat tidak tertulis tetapi digunakan secara terus menerus dan bersifat dinamis.

AUPB berhubungan dengan efisiensi penyelenggaraan pemerintahan, masyarakat yang secara aktif berpartisipasi dengan mengutamakan persamaan hak dan prinsip negara hukum. Masyarakat menyadari bahwa penyelenggaraan pemerintahan harus mengutamakan persamaan di depan hukum, perlindungan hukum serta kepastian hukum. Peran aktif masyarakat modern dapat dilakukan melalui proses pembuatan hukum dan penegakan hukum yaitu dengan memberikan informasi, kerjasama, prinsip keterbukaan. Dikemukakan oleh Gio ten Berge, ada pergeseran untuk menyeimbangkan hak dan kewajiban warga negara sehingga hal ini terkait dengan masyarakat modern yaitu tuntutan pemerintahan yang transparan, kerjasama. ${ }^{12}$ Kebutuhan akan pemerintahan yang transparan, akuntabel dan cepat, nampaknya sudah menjadi tuntutan masyarakat modern yang tentu saja berbeda dengan masyarakat sebelum timbul arus modernisasi dan globalisasi.

Kualitas pelayanan pemerintahan yang baik, tetap harus berdasar AUPB baik yang tercantum dalam perundangan maupun yang berasal dari kebiasaan, norma. Penyelenggaraan pelayanan publik oleh Pemerintah, menurut Ridwan tidak dapat dipisahkan dari jabatan dan pejabat, sehingga timbul 2 (dua) entitas penting yaitu norma pemerintahan dan norma perilaku aparat. Norma pemerintahan adalah kaidah hukum tertulis dan tidak tertulis yang berlaku terhadap jabatan pemerintahan, sedangkan norma perilaku aparat yaitu kaidah hukum tertulis dan tidak tertulis yang harus diperhatikan dan dipatuhi oleh pemangku jabatan. ${ }^{13}$ AUPB berlaku sebagai norma pemerintahan bersamaan dengan norma perilaku aparat, jadi tidak dapat dipisahkan. Perlu dipahami bahwa dalam menyusun surat keputusan di dalamnya akan tercakup pula norma pemerintahan serta norma perilaku aparat, apakah keputusan yang dibuat sudah sesuai dengan prosedur yang ditentukan, serta apakah juga sudah sesuai dengan asas keterbukaan, kecermatan, asas ketidakberpihakan dan asas-asas pemerintahan lain baik yang tertulis maupun tidak tertulis.

Menurut Supandi bahwa pelayanan publik adalah tanggung jawab pemerintah, yang didalamnya mengandung unsur perhatian dan kesiapan dan kesediaan pegawai pemerintah., sedangkan kualitas pelayanan yang diinginkan adalah pelayanan yang sesuai keinginan maupun melebihi standar pelayanan yang telah ada. ${ }^{14}$ Pejabat dan/atau Badan Tata Usaha Negara perlu menyadari kedudukan untuk memberikan pelayanan publik (public service) sesuai dengan hak sipil warga negara, dengan mengutamakan prinsip persamaan di depan hukum dan pemerintahan sebagaimana sudah diatur dalam Pasal 27 UUD NKRI Tahun 1945. Selain mengutamakan prinsip tersebut, masih ada beberapa prinsip keterbukaan dan kepastian hukum sebagai dasar utama suatu negara hukum.

Paradigma baru yang terkandung dalam UU No 30 Tahun 2014 tentang Administrasi Pemerintahan, perlu diikuti dengan perubahan tata cara penyelenggaraan pemerintahan, artinya dengan lebih mengutamakan kualitas pelayanan publik, termasuk pula adalah penerbitan surat keputusan. Untuk terbitnya surat keputusan harus diikuti seluruh standar prosedur meliputi kewenangan, prosedur serta substansi yang akan dicantumkan. Tata cara penyelenggaraan pemerintahan yang baik perlu dimulai dari tingkat daerah atau tingkat yang paling rendah secara organisatoris hingga tingkat pusat. Diabaikannya AUPB jelas sangat merugikan

\footnotetext{
G Ten Berge, “Towards an Equilibrium between Citizens 'Rights and Civic Duties in Relation to Government”, Utrecht Law Review, Vol. 63, No. 2, Juni, 2007, hlm. 219-26.

13 Ridwan, 2014, Diskresi Dan Tanggung Jawab Pemerintah, FH UII Press, Yogyakarta, hlm. 157.

14 Supandi, 2016, Urgensi Reformasi Hukum Acara Perdata aan Hukum Acara Peradilan Tata Usaha Negara dalam Era Pembangunan Hukum Modern, Alumni, Bandung, hlm. 116-123.
} 
baik secara individu maupun secara keseluruhan yaitu untuk warga masyarakat.

Sebagaimana diketahui bahwa AUPB berasal dari praktek di negara Barat, namun demikian setiap negara memiliki nilai sejarah, budaya, kebiasaan yang tentu memberi pengaruh dalam pembentukan AUPB di negara tersebut. Hal ini sebagaimana dikemukakan oleh W. Zhicheng, "... differences in historical tradition, actual systems, developmental level and national conditions determine that some of the requirements and indicators of global good governance are not in reality applicable to the governance of all countries.". ${ }^{15}$ Jenis AUPB yang tercantum dalam 10 UUAP berbeda dengan principle of good governance dari organisasi international maupun negara lain, meskipun demikian tetap ada prinsip yang secara umum diterima dan digunakan.

UU AP merupakan paradigma baru di bidang penyelenggaraan pemerintahan, sehingga hal tersebut menjadi salah satu titik tolak untuk mengetahui tata kelola pemerintahan, serta pergeseran paradigma bagi Pengadilan Tata Usaha Negara. Sebagai paradigma baru dalam penyelenggaraan pemerintahan sehingga perlu perubahan cara berpikir atau cara bertindak bagi Pejabat dan/atau Badan Tata Usaha Negara, serta kualitas pelayanan yang lebih baik.

Tata kelola pemerintahan yang baik semakin menjadi perhatian publik terutama dikaitkan dengan pelayanan publik oleh pemerintah. Dikutip dari Abdun Nooryang menyebutkan "...good governance is now an acceptable goals for public servants in developing countries ...to be more transparents and fair in all of their transactions and respons with integrity to the demands of citizens. "16 Lebih lanjut dijelaskan bahwa efektivitas dan efisiensi adalah kunci utama dalam peningkatan pelayanan publik. Dalam kaitannya dengan pelayanan publik di pemerintahan saat ini, memang masih perlu ditingkatkan dari sisi kualitas pelayanan, hal yang sering mendapat perhatian dari masyarakat.

Pelayanan publik yang baik, transparan, akuntabel, efektif dan efisien, menjadi hal utama bagi peningkatan tata kelola pemerintahan. Hal tersebut juga dikemukakan dalam "Good Governance and Organization Performance in Public Sector: A Proposed Framework" bahwa "... good governance in current perspective specifically to efficient service delivery and improvement in the performance in the public sector. "17 Pentingnya peningkatan kapasitas, akuntabilitas yang dimiliki oleh Pemerintah agar kualitas pelayanan publik menjadi lebih baik memang harus ditingkatkan, namun demikian ada beberapa faktor yang mempengaruhi hal tersebut.

Tata kelola pemerintahan yang baik juga harus diikuti dengan reformasi birokrasi yang sudah diupayakan oleh Pemerintah melalui beberapa institusi mulai tahun 2018 yang selanjutnya diperluas menjadi 75 institusi pada tahun 2014.Dikemukakan oleh Arif Budy Pratama, bahwa aspek kebudayaan memiliki peran penting dalam reformasi birokrasi. ${ }^{18}$

Sesuai dengan perkembangan informasi teknologi yang juga menuntut dilakukan penyesuaian terhadap pelbagai jenis tindakan hukum pemerintah, dengan mulai digunakannya pelbagai aplikasi permohonan, bentuk keputusan elektronik, alat bukti elektronik dan hal lain terkait, yang mendorong dikembangkan ke arah e-government. Perkembangan dan penyesuaian peraturan perundangan yang mendukung, terus dilakukan Pemerintah dengan tetap mengutamakan peningkatan tata kelola pemerintah yang baik, serta AUPB yang terus berkembang mengikuti perkembangan era digital.

Penelitian yang dilakukan di Bangladesh oleh Sharif N As - Saber dkk., menyebutkan bahwa penggunaan kemajuan teknologi informasi untuk mendukung penyelenggaraan pemerintahan belum

\footnotetext{
Wu Zhicheng, "The Influence of Global Governance upon State Governance”, Social Sciences in China, Vol. 37, No. 4, 2016, hlm. 164-74. Abdun Noor, "Ethics, Religion and Good Governance", Joagg, Vol 3, No. 2, Desember, 2008, hlm. 62-77.

Mohd Khirul Azwan Mohd Kamal, et al., "Good Governance and Organization Performance in Public Sector : A Proposed Framework", International Journal of Administration and Governance, Vol. 1, No. 4, 2015, hlm. 63-68.

18 Arif Budy Pratama, "Bureaucracy Reform Deficit in Indonesia: A Cultural Theory Perspective", Journal of Public Administration and Governance, Vol 7, No. 3, September, 2017, hlm. 88-99.
} 
dapat terlaksana sebagaimana yang diharapkan, karena masih banyak hambatan di sektor peraturan perundang-undangan serta penegakan hukum. Perlu dibangun suatu kerangka hukum yang mendukung penerapan internet di berbagai aspek kehidupan masyarakat dan negara. ${ }^{19}$ Kendala yang dihadapi Bangladesh mengakibatkan belum dapat terlaksana dengan baik atau sesuai dengan rencana pengembangan yang dibuat oleh Pemerintah, namun demikian upaya untuk memulai suatu pembangunan yang sesuai dengan globalisasi, sudah mulai diupayakan. Untuk dapat menyesuaikan dengan perkembangan teknologi informasi, perlu ditingkatkan kemampuan pemahaman tentang tata kelola pemerintahan yang baik, karena tuntutan masyarakat semakin bertambah mengikuti perkembangan yang terjadi.

Suatu konsep kerangka kerja (conceptual framework) di kemukakan oleh Muhd. KhirulAzwan Mohd Kamal dkk., mengenai hubungan antara tata kelola pemerintah yang baik dengan performa atau tata cara pengorganisasian yang didukung oleh kepemimpinan, pemangku kepentingan, pengawasan, akuntabilitas, manajemen risiko (risk management) serta strategi manajemen (strategic management $){ }^{20}$ Konsep di atas berdasarkan hasil penelitian di Malaysia mengenai kurangnya penelitian tentang kinerja pemerintahan di sektor publik. Dalam kerangka berpikir bahwa pemerintahan memberi pelayanan publik, maka konsep kerangka kerja yang diperlukan untuk meningkatkan kinerja pemerintah adalah dengan menyatukan strategi manajemen pelayanan publik yang harus memiliki kepemimpinan yang kuat, akuntabilitas, perlu pengawasan yang transparan serta memperhitungkan kemungkinan resiko yang akan timbul dengan melibatkan semua pihak yang berkepentingan baik langsung maupun tidak langsung terhadap pelayanan pemerintah.
Di Belanda setelah dikeluarkannya General Administrative Law Act (GALA), terdapat beberapa pergeseran mengenai pemerintahan, termasuk di antaranya hukum administrasi negara serta penyelenggaraan pemerintahan, yang antara lain menyebutkan “... that modern law requires a government that no longer presents itself as an entity above citizens, but rather as a legal actor besides citizens, mutually entangled in compound network of "reciprocal legal relations' that requires legal protection of the justified expectations of all parties involved". ${ }^{21}$ Posisi pemerintah adalah berdampingan dengan warga negara, tidak pada posisi yang lebih tinggi, sehingga hal ini diharapkan dapat meningkatkan kualitas pelayanan pemerintahan. Ide dasar tersebut perlu untuk dikaji lebih lanjut apabila akan digunakan untuk meningkatkan pelayanan pemerintah di Indonesia.

Menurut G.H. Addink, perkembangan AUPB secara internasional, lokal, regional adalah sangat penting, karena terkait dengan praktek malfungsi administrasi di berbagai institusi, kompleksitas pemerintahan modern yang memerlukan dukungan administratif yang lebih berkualitas, masalah fragmentasi norma hukum terkait dengan kepastian hukum dan kualitas. Adanya interaksi antara: rule of law, democracy, good governance dalam penyelenggaraan pemerintahan. Adapun kesimpulan yang disampaikan oleh G.H. Addink, sebagai berikut: ${ }^{22}$

1. There is a need for good governance in a modern state and common understanding

2. Concept and principles of good goverance has been developed on international and national level in theory and practice

3. Six key principles: properness, transparency, participation, effectiveness, accountability and human rights. Links with integrity

19 Khalid Hossain As-Sabe, et al., "Information Technology Law and E-Government : A Developing Country Perspective", JOAAG, Vol. 1, No. 1, Desember ,2006, hlm 84-101.

20 Mohd Khirul Azwan Mohd Kamal, et al., "Good Governance and Organization Performance in Public Sector : A Proposed Framework", International Journal of Administration and Governance, Vol. 1, Issue 4, hlm. 63-68.

21 Lukas Van Den Berge, "The Relational Turn in Dutch Administrative Law", Utrecht Law Review, Vol 13, No. 1, Januari, 2017, hlm. 99-111.

22 G.H. Addink, 2017, "Good Governance in Theory and Practice", Makalah, International Conference on Law, Governance and Globalisation, Fakultas Hukum Universitas Airlangga, Surabaya, Tanggal 16-17 November 2017, hlm. 3. 
4. Effectiveness of principles: the CLEAR model and toolkit

5. In the annex some publications.

Tata kelola pemerintahan yang baik perlu dibangun dengan memperhatikan dan melaksanakan AUPB secara benar, tanpa mengurangi nilai - nilai setiap bangsa, namun justru mendasarkan AUPB pada hal tersebut. Meningkatnya tuntutan dari masyarakat untuk memperoleh pelayanan publik yang transparan, akuntabel dan tidak bersifat maladministrasi, perlu mendapat perhatian dari Pemerintah, dengan meningkatkan pemahaman untuk menggunakan AUPB dengan benar dan tepat. AUPB terus akan berkembang sesuai dengan perkembangan pemerintahan, masyarakat dan peran yurisprudensi dalam sistem hukum nasional.

\section{Peran Pengadilan Tata Usaha Negara untuk membangun tata kelola pemerin- tahan yang baik.}

Sebagai negara hukum serta asas negara hukum, setiap tindakan hukum Pemerintah, baik di bidang hukum publik maupun privat harus berdasarkan hukum tertulis yang berlaku, mengutamakan perlindungan hukum bagi warga negara, jaminan persamaan hak . Peran Pengadilan Tata Usaha Negara untuk melakukan fungsi pengawasan, adalah penting sebagai fungsi pengawasan yang bersifat eksternal serta a-posteriori.

Pelaksanaan fungsi PTUN dalam hal fungsi pengawasan terhadap penyelenggaraan pemerintahan yang dilakukan bersama dengan fungsi peradilan yaitu melalui putusan Hakim yang didalamnya mengandung epistemologi dan aksiologi putusan. PTUN selain melaksanakan fungsi peradilan juga melaksanakan fungsi pengawasan yuridis, yang dikemukakan oleh Prajudi Atmosudirdjo bahwa kehadiran peradilan adminsitrasi adalah untuk mengembangkan dan memelihara administrasi negara yang tepat menurut hukum (rechtmatig) atau tepat menurut undang-undang (wetmatig) atau tepat secara fungsional (efektif) dan berfungsi secara efisien. ${ }^{23}$ Sesuai dengan tugas Hakim dalam UndangUndang Nomor 48 Tahun 2009 tentang Kekuasaan Kehakiman, putusan Hakim dapat menemukan hukum sesuai dengan kondisi yang ada, melakukan pembaharuan hukum atau menciptakan hukum, terutama untuk menggali AUPB yang timbul dari praktek pemerintahan. ${ }^{24}$ Putusan Hakim adalah hukum yang hidup (law in action) yang berbeda dengan peraturan perundang-undangan (law in books), harus dilihat sebagai suatu dinamika ke arah pembangunan hukum.

Secara umum, perkembangan yurisprudensi di Indonesia perlu ditingkatkan terutama dalam konsep pembangunan hukum Nasional. Artinya pembangunan hukum tidak saja dilakukan melalui pembentukan peraturan perundang-undangan, tetapi yurisprudensi harus lebih diberdayakan. Di masyarakat luas, perbedaan antara yurisprudensi dengan putusan hakim masih perlu diperjelas secara teknis, Bagir Manan membedakan sifat antara yurisprudensi dengan putusan hakim, yaitu yurisprudensi adalah hukum positif yang berlaku secara umum yang lahir atau berasal dari putusan hakim, sementara putusan hakim adalah hukum yang bersifat konkrit dan khusus berlaku pada subyek yang terkena atau terkait langsung dengan bunyi putusan. Ketika putusan hakim diterima sebagai yurisprudensi, maka asas atau kaidahnya menjadi bersifat umum dan dapat dipergunakan sebagai dasar pertimbangan hukum bagi siapa saja. ${ }^{25}$ Kekhususan dalam PTUN adalah putusan Hakim yang bersifat erga omnes yaitu bahwa putusan PTUN bersifat mengikat publik. ${ }^{26}$

Dalam disertasi Teguh Satya Bhakti, yang mengambil tabulasi kuesioner yang dilakukan 
oleh Puslitbang Kumdil MARI pada tahun 2005 dengan topik "Pembentukan Hukum Melalui Yurisprudensi", bahwa suatu putusan hakim dapat disebut sebagai yurisprudensi bilamana memenuhi unsur-unsur sebagai berikut : ${ }^{27}$

a. Keputusan atas sesuatu peristiwa apa hukumnya apabila belum jelas pengaturan perundang-undangannya;

b. Keputusan tersebut harus sudah merupakan tetap;

c. Telah berulang kali diputus dengan keputusan yang sama dalam kasus yang sama;

d. Memenuhi rasa keadilan;

e. Keputusan itu dibenarkan oleh Mahkamah Agung; dan

f. Mengandung obiter dicta dan ratio decidendi.

Dari kriteria yang dikemukakan di atas, Teguh Satya Bhakti berpendapat bahwa kriteria dari Badan Pembinaan Hukum Nasional (BPHN) dan Mahkamah Agung mengenai unsur telah berulang-ulang kali diputus dengan keputusan yang sama dalam kasus yang sama, adalah sulit diterapkan karena sistem hukum Indonesia tidak mengadopsi asas stare decisis atau binding precedent dalam sistem peradilannya. ${ }^{28}$ Dalam kerangka pembangunan hukum Nasional, perkembangan di masyarakat, globalisasi dan modernisasi di berbagai aspek, perlu untuk dikaji lebih lanjut mengenai pentingnya mengadopsi asas stare decisis. Dinamika penyelenggaraan pemerintahan yang sejajar dengan perkembangan masyarakat jelas membutuhkan pengaturan yang jelas dan dapat mengikuti perkembangan, sehingga diperlukan yurisprudensi. Peran yurisprudensi dalam memperkuat AUPB sangat penting, hal ini karena AUPB yang dicantumkan dalam putusan pengadilan serta memiliki kekuatan hukum tetap, dapat digunakan dalam penyelenggaraan pemerintahan.

Putusan Hakim yang didalamnya mencan- tumkan AUPB, baik yang sudah disebutkan dalam perundang-undangan maupun yang berasal dari penemuan hukum berdasarkan praktek penyelenggaraan pemerintahan, dapat menjadi putusan yang memiliki manfaat secara teori maupun praktek. Alasan yang menjadi dasar adalah, pertama, Hakim melakukan tugas untuk menggali, mengikuti dan memahami nilai-nilai hukum dan rasa keadilan yang hidup di masyarakat, hal ini terkait dengan AUPB yang berasal dari nilai yang hidup di masyarakat. Secara teori, akan menambah AUPB selain yang sudah ada dalam perundangan. Kedua, secara praktek, putusan Hakim yang berkekuatan hukum tetap, dapat menjadi yurisprudensi di bidang pemerintahan. Sehingga juga memiliki kegunaan sebagai parameter dalam penyelenggaraan pemerintahan.

Putusan PTUN tentang AUPB selalu mengikuti perkembangan praktik-praktik penyelenggaraan pemerintahan, hal ini karena di dasarkan pada setiap kasus memiliki AUPB yang berbeda sebagai batu uji terhadap obyek sengketa. Di kemukakan oleh Wakil Ketua Pengadilan Tata Usaha Negara Bandung, penerapan AUPB sebagai batu uji terhadap pemeriksaan sengketa, diserahkan kepada Hakim. Artinya, tidak selalu terikat atau mengikuti AUPB yang tercantum dalam hukum positif, karena penerapan AUPB dalam penyelenggaraan pemerintahan juga didasarkan pada kewengan bebas yang tetap terikat pada perundangan.

Kepala Panitera PTUN Denpasar juga berpendapat bahwa dengan diundangkannya UU AP diharapkan semakin meningkatkan kesadaran masyarakat untuk memanfaatkan PTUN sebagai sarana pencarian keadilan berdasarkan AUPB sehingga semakin mendorong pemerintah / pejabat administrasi negara dalam memberikan pelayanan yang maksimal kepada masyarakat khususnya di bidang pelayanan publik.

AUPB memiliki 3 fungsi yang berbeda dilihat dari penerapannya, hal ini disampaikan

\footnotetext{
27 Teguh Satya Bhakti, 2017, Pembangunan Hukum Administrasi Negara Melalui Pemberdayaan Yurisprudensi Peradilan Tata Usaha Negara, Thesis, Universitas Diponegoro, Semarang, hlm. 288.

$28 \quad$ Ibid., hlm 289.
} 
oleh Husein, S.H., ${ }^{29}$ yaitu pertama, sebagai alat kontrol bagi Pemerintah dalam melaksanakan pemerintahan, kedua, sebagai alat uji bagi PTUN, ketiga sebagai alasan untuk mengajukan gugatan oleh Penggugat. Tiga fungsi yang dimiliki oleh AUPB ini, menunjukkan peran penting AUPB dalam penyelenggaraan pemerintahan.

Diperlukan putusan Hakim yang berkekuatan hukum tetap, agar AUPB dapat dilaksanakan oleh pemerintah, namun demikian pelbagai faktor teknis maupun non teknis mempengaruhi pelaksanaan putusan PTUN yang berkekuatan hukum tetap, artinya tidak selamanya faktor ketaatan hukum pejabat pemerintah menjadi penentu terlaksananya putusan pengadilan. ${ }^{30}$ Pemerintah perlu membangun sikap untuk mentaati putusan pengadilan yang telah berkekuatan hukum tetap, hal ini penting terkait dengan fungsi pemerintah sebagai pelayan publik. Sikap untuk melaksanakan putusan Hakim yang berkekuatan hukum tetap juga merupakan salah satu wujud asas ketaatan hukum yang berlaku bagi semua pihak.

Putusan Hakim tetap harus berdasarkan akuntabilitas dan transparansi, hal ini untuk menjamin kebebasan Hakim dalam memutus sengketa. Dalam putusan Hakim harus dapat memberi manfaat secara teori dan praktek. Terkait dengan AUPB, Hakim dapat melakukan penemuan, pembentukan hukum melalui interpretasi, argumentasi maupun konstruksi hukum. Melalui proses penalaran hukum inilah yang dapat putusan hakim memberi manfaat secara teoritis, AUPB yang dicantumkan dapat menambah, memperkuat kedudukan AUPB dalam pemerintahan, secara praktek AUPB harus diterapkan secara benar.

\section{Kesimpulan}

Berdasarkan kajian yang telah dilakukan, dapat disimpulkan bahwa perkembangan AUPB dikaitkan dengan Undang-Undang Nomor 30 Tahun 2104 tentang Administrasi Pemerintahan yaitu sebagai syarat materiil mengajukan gugatan ke PTUN. Syarat materiil sesuai Pasal 53 ayat (2) Undang-Undang Nomor 9 Tahun 2004 salah satunya adalah bertentangan dengan AUPB sebagaimana diatur dalam Undang-Undang Nomor 28 Tahun 1999 tentang Penyelenggaraan Negara yang Bersih, Bebas dari Korupsi, Kolusi dan Nepotisme. Dicantumkannya AUPB dalam Pasal 10 ayat (1) dan (2) UU AP untuk melengkapi, memperjelas peran AUPB untuk membangun tata kelola pemerintahan yang baik. Perkembangan AUPB di Indonesia dibagi dalam 3 fase. Mulai dari secara tidak tertulis yaitu berdasarkan konsep, doktrin, kebiasaan yang timbul dalam praktek penyelenggaraan negara, hingga diatur dalam peraturan perundangan. Kekurangpahaman maupun kekurangtelitian dalam menempatkan AUPB sebagai dasar penyusunan keputusan, dapat menjadi penyebab gugatan di PTUN. AUPB sebagai suatu asas yang diatur secara normatif namun penerapannya yaitu untuk penyusunan keputusan dan/atau tindakan belum sepenuhnya diterapkan. Kewajiban bagi setiap pihak yang berkepentingan terhadap pemerintahan untuk menempatkan AUPB sebagai hal utama. Pemerintah sebagai penyelenggara pemerintahan harus berhati-hati, cermat dan teliti dalam setiap penyusunan keputusan dan/atau tindakan yang dibuat dan/atau dilakukan.

Peran PTUN untuk membangun tata kelola pemerintahan yang baik, dilakukan melalui putusan Hakim. Dalam putusan Hakim dapat dilihat perkembangan AUPB yang tercantum dalam pertimbangan hukum Hakim. Sesuai dengan tugas Hakim yaitu untuk memeriksa, memutus sengketa tata usaha negara dan untuk menggali, mengikuti, memahami nilai-nilai hukum dan rasa keadilan yang hidup di masyarakat, hal ini terkait dengan AUPB yang berasal dari nilai yang hidup di masyarakat. Secara teori, akan menambah AUPB selain yang sudah ada dalam perundangan. Secara praktek, putusan Hakim yang berkekuatan hukum 
tetap, dapat menjadi yurisprudensi di bidang pemerintahan .Peran PTUN melalui putusan Hakim adalah karena di dalam pertimbangan hukum Hakim dapat dilakukan penemuan hukum terkait AUPB, sehingga dapat digunakan untuk meningkatkan tata kelola pemerintahan.

\section{DAFTAR PUSTAKA}

\section{A. Buku}

Abdoellah, Priyatmanto, 2016, Revitalisasi Kewenangan PTUN Gagasan Perluasan Kompetensi Peradilan Tata Usaha Negara, Cahaya Atma Pustaka, Yogyakarta.

Abdullah, Ali, 2017, Teori Dan Praktik Hukum Acara Peradilan Tata Usaha Negara, Kencana, Jakarta.

Asmuni, 2017, Konsep Pelaksanaan Keputusan Tata Usaha Negara Penundaan Pelaksanaan Keputusan Tata Usaha Negara Oleh Pengadilan Tata Usaha Negara, Setara Press, Malang.

Dani, Umar, 2015, Putusan Pengadilan NonExecutable Proses Dan Dinamika Dalam Konteks PTUN, Genta Publishing, Yogyakarta.

Fachruddin, Irfan , 2004, Pengawasan Peradilan Administrasi Terhadap Tindakan Pemerintah, Alumni, Bandung.

Addink, G.H., 2017, "Good Governance in Theory and Practice", Fakultas Hukum Universitas Airlangga, Surabaya.

Manan, Bagir, 2009, Menegakkan Hukum Suatu Pencarian, Asosiasi Advokat Indonesia, Jakarta.

Manan, Bagir, 2004, Hukum Positif Indonesia, FH UII, Yogyakarta.

Marbun, S.F., 2014, Asas-Asas Umum Pemerintahan Yang Layak, FH UII Press, Yogyakarta.

Mawardi, Irfan, 2016, Paradigma Baru PTUN Respon Peradilan Administrasi Terhadap Demokratisasi, Thafa Media, Yogyakarta.

Ridwan, 2014, Diskresi Dan Tanggung Jawab Pemerintah, FH UII Press, Yogyakarta.

Setya, Cekli et al., 2017, Asas-Asas Umum Pemerintahan Yang Baik Dalam Perkara
Tata Usaha Negara, Lembaga Kajian dan Advokasi Independensi Peradilan Judicial Sector Support Program, Jakarta.

Supandi, 2016, Hukum Peradilan Tata Usaha Negara, Alumni, Bandung.

Supandi, 2016, Urgensi Reformasi Hukum Acara Perdata Dan Hukum Acara Peradilan Tata Usaha Negara Dalam Era Pembangunan Hukum Modern, Alumni, Bandung.

\section{B. Artikel Jurnal}

Berge, G Ten, "Towards an Equilibrium between Citizens ' Rights and Civic Duties in Relation to Government", Utrecht Law Review, Vol. 63, No. 2, Juni, 2007.

Berge, Lukas Van Den,"The Relational Turn in Dutch Administrative Law", Utrecht Law Review, Vol 13, No. 1, Januari, 2017.

Hossain, Khalid As-Sabe, et al., "Information Technology Law and E-Government: A Developing Country Perspective", JOAAG, Vol. 1, No. 1, Desember ,2006.

Kamal, Mohd Khirul Azwan Mohd, et al., "Good Governance and Organization Performance in Public Sector : A Proposed Framework", International Journal of Administration and Governance, Vol. 1, No. 4, 2015.

$\mathrm{Ng}$, Michael Chi Man, "Are Globalization and Governance Interrelated? Evidence Among World Economics", Journal of Globalization Studies, Vol. 7, No. 2, November, 2016.

Noor, Abdun, "Ethics, Religion and Good Governance", Joaag, Vol 3, No. 2, Desember, 2008.

Pratama, Arif Budy, "Bureaucracy Reform Deficit in Indonesia: A Cultural Theory Perspective", Journal of Public Administration and 
Governance, Vol. 7, No. 3, September, 2017. Shidarta, B. Arief, "Kajian Kefilsafatan Tentang Negara Hukum", Jentera, Edisi III, Tahun II, November 2004.

Zhicheng, $\mathrm{Wu}$, “The Influence of Global Governance upon State Governance", Social Sciences in China, Vol. 37, No. 4, 2016.

\section{Antologi}

Rivai, Yulius, "Putusan Hakim Sebagai Suatu Ilmu", in Subur, et al., 2014, Bunga Rampai Peradilan Administrasi Kontemporer, Genta Publishing, Yogyakarta. 